\title{
Penerapan Supervisi Akademik Berbasis Coaching untuk Meningkatkan Kemampuan Mengajar Guru MAN 2 Ketapang Semester Ganjil Tahun Pembelajaran 2018/2019
}

\author{
Chaidir \\ Madrasah Aliyah Negeri 2 Ketapang,Kalimantan Barat, Indonesia
}

Corresponding Author : balyachaidir@gmail.com

\begin{tabular}{ll}
\hline & \multicolumn{1}{c}{ ABSTRACT } \\
\cline { 2 - 3 } & Penelitian ini bertujuan untuk untuk mengetahui peningkatan \\
kemampuan mengajar Guru Bidang Studi dalam menerapkan strategi \\
pembelajaran inkuiri (SPI) melalui penerapan supervisi akademik \\
berbasis coaching. Subjek dalam penelitian ini adalah beberapa guru \\
bidang studi di MAN 2 Ketapang yang berjumlah 5 orang, dengan fokus \\
penelitian adalah kemampuan guru menyusun rencana pelaksanaan \\
pembelajaran (RPP), melaksanakan pembelajaran dengan SPI, dan \\
ketuntasan klasikal siswa dalam pembelajaran tersebut. Desain penelitian \\
menggunakan rancangan penelitian tindakan sekolah sebanyak 2 siklus \\
dengan tahapan perencanaan, tindakan, observasi, dan refleksi. Pada \\
siklus pertama rata-rata kemampuan guru menyusun RPP mencapai skor \\
75,71\%, kemampuan guru melaksanakan pembelajaran dengan SPI \\
mencapai skor 67,50\%, dan terdapat 2 kelas dengan ketuntasan klasikal \\
dengan ketuntasan klasikal dibawah 85\% dengan rata-rata keseluruhan \\
89,52\%. Pada siklus kedua dicapai hasil bahwa rata-rata kemampuan \\
guru menyusun RPP mencapai skor 97,14\%, kemampuan guru dalam \\
melaksanakan pembelajaran SPI mencapai 87,22\%, dan persentase \\
ketuntasan klasikal siswa minimal 85,71\% hanya pada satu kelas. Dengan \\
demikian hasil penelitian ini menunjukkan penerapan supervisi \\
akademik berbasis coaching dapat meningkatkan kemampuan guru dalam \\
menerapkan strategi pembelajaran inkuiri.
\end{tabular}

\section{PENDAHULUAN}

Tiga pilar utama yang menunjukkan bahwa guru telah mampu bekerja secara profesional dalam melaksanakan tugas kependidikan adalah (a) menguasai materi pembelajaran, (b) profesional dalam menyampaikan materi pembelajaran kepada siswa, dan (c) berkepribadian matang (Aqib dan Rohmanto, 2007:47). Tiga pilar tersebut saling terkait dan mendukung satu sama lain untuk meningkatkan kinerja pembelajaran. Kinerja pembelajaran menentukan tingkat keberhasilan dan kesesuaian hasil belajar siswa dengan tujuan yang telah ditentukan. Sedangkan tingkat keberhasilan dan kesesuaian 
Page : $70-82$

hasil belajar siswa dengan tujuan sangat dipengaruhi oleh kinerja guru. Seiring dengan berjalannya waktu, kemampuan guru dalam penguasaan materi pembelajaran, penyampaian materi pembelajaran, dan kepribadiannya diharapkan semakin meningkat, sehingga mampu membangun suasana pembelajaran yang produktif, kreatif, dan inovatif, yakni suatu pembelajaran yang mampu meningkatkan mutu lulusan.

Supervisi terhadap pembelajaran harus dilakukan secara rutin dan berkesinambungan. Supervisi yang dilaksanakan di sekolah memberikan peluang dan kesempatan kepada guru untuk mengembangkan kemampuan profesional mereka. Kemampuan profesional ini tercermin pada kemampuan guru memberikan bantuan belajar kepada siswanya. Sehingga terjadi perubahan perilaku. Supervisi harus dilaksanakan oleh supervisor secara konstruktif dan kreatif dengan cara mendorong inisiatif guru untuk ikut aktif menciptakan suasana kondusif yang dapat membangkitkan suasana kreativitas siswa dalam belajar (Sagala, 2010:95).

Salah satu kewajiban guru sebelum melaksanakan pembelajaran adalah menyusun perangkat pembelajaran. RPP merupakan pedoman dan arahan tentang kegiatan yang akan dilakukan selama proses pembelajaran oleh guru dari awal sampai dengan berakhirnya pembelajaran. Dalam arti bahwa agar apa yang diinginkan setelah proses pembelajaran berlangsung para peserta didik dapat mencapai tujuan-tujuan pembelajaran tertentu sebagaimana yang ditentukan. Jika proses pembelajaran yang dilakukan tidak sesuai dengan apa yang telah direncanakan dalam RPP sebelumnya, tentu sudah bisa dipastikan bahwa proses pembelajaran akan berjalan tanpa arah dan tujuan yang jelas (Suhatman, 2016:1).

Gordon dalam Mulyasa (2005:53) merinci beberapa aspek ranah yang ada dalam konsep kompetensi, yakni (1) pengetahuan (knowledge) yaitu kesadaran dalam bidang kognitif; (2) pemahaman (understanding): kedalaman kognitif dan afektif yang dimiliki oleh individu; (3) kemampuan (skill) yaitu sesuatu yang dimiliki oleh seseorang untuk melakukan tugas atau pekerjaan yang dibebankan kepadanya; (4) nilai yaitu suatu standar perilaku yang telah diyakini dan secara psikologis telah menyatu dalam diri seseorang; (5) sikap yaitu perasaan atau reaksi terhadap suatu rangsangan yang datang dari luar; dan (6) minat (interest) yaitu kecenderungan seseorang untuk melakukan sesuatu perbuatan.

Pembelajaran inkuiri menurut Colburn (2000:42) dalam jurnal "An Inquiry Primer" bahwa inkuiri sebagai penciptaan atau pengolahan kelas dimana siswa dilibatkan dalam dasar-dasar pemecahan masalah melalui diskusi berpusat pada siswa, dan aktivitas-aktivitas yang dilakukan oleh siswa. Pembelajaran inkuri termasuk dalam rumpun pembelajaran pemrosesan informasi (Joyce dkk, 2011:183). Dalam pembelajaran model penelitian ilmiah atau latihan penelitian dinyatakan bahwa inti model pembelajaran ini adalah melibatkan siswa dalam masalah penelitian yang benar-benar orisinil dengan cara menghadapkan mereka pada bidang investigasi, membantu mereka 
Ability : Journal of Education and Social Analysis

Volume 2, Issue 3, Juli 2021

Page : 70-82

mengidentifikasi masalah konseptual atau metodologis dalam bidang tersebut, dan mengajak meraka untuk bisa melihat bagaimana suatu pengetahuan dibuat dan dibangun dalam komunitas para ilmuan. Konsep supervisi modern dirumuskan oleh Wiles (1967) yang dikutip oleh Muslim (2009:38) adalah "Supervision is assistance in the development of a better teaching-learning situation. Rumusan ini mengisyaratkan bahwa layanan supervisi meliputi keseluruhan situasi belajar mengajar. Definisinya mengerucut pada masalah pembelajaran, maka ada penyebutan supervisi yang demikian termasuk supervisi pembelajaran

\section{METODE PENELITIAN}

Penelitian dilaksanakan MAN 2 Ketapang pada tanggal 01 Agustus s/d 30 November 2018 kelas X IPA dan X IPS . Subjek penelitian adalah beberapa guru lintas bidang studi yakni sebanyak 5 orang. Penelitian dilaksanakan dalam rangkaian penelitian tindakan (action research) yang terpadu dalam pemberian tindakan supervisi akademik berbasis coaching. Tahapan coaching terdiri dari 6 (enam) tahapan yakni klarifikasi tujuan, menyepakati kebutuhan pengembangan, merumuskan perencanaan, melaksanakan tugas/aktifitas, meninjau kembali, dan mengakhiri coaching. Coaching dilaksanakan secara individual (percakapan individu) terhadap 5 orang guru subjek penelitian. Data penelitian akan dikumpulkan dengan cara menilai kemampuan guru dalam merencanakan pembelajaran inkuiri melalui lembar penilaian RPP, menilai kemampuan guru melaksanakan strategi pembelajaran inkuiri melalui lembar observasi pembelajaran, menilai persentase ketercapaian ketuntasan klasikal siswa berdasarkan data tes hasil belajar siswa, wawancara, untuk mengumpulkan data selama pelaksanaan kegiatan coaching dan dokumentasi/ perekaman video pelaksanaan pembelajaran inkuiri dengan menggunakan camera video.

\section{HASIL DAN PEMBAHASAN}

Hasil telaah kemampuan guru menyusun RPP pada siklus 1 disajikan pada tabel berikut;

Tabel 1. Rekapitulasi kemampuan guru menyusun RPP Siklus 1

\begin{tabular}{|c|l|c|c|c|c|c|c|c|}
\hline \multirow{2}{*}{ No } & Aspek yang dinilai & \multicolumn{5}{|c|}{ Guru } & \multicolumn{2}{c|}{ Rata-rata } \\
\cline { 2 - 9 } & G1 & G2 & G3 & G4 & G5 & Skor & $\%$ \\
\hline 1 & $\begin{array}{l}\text { Merumuskan tujuan } \\
\text { pembelajaran }\end{array}$ & 3 & 3 & 3 & 3 & 3 & 3.00 & 75.00 \\
\hline 2 & $\begin{array}{l}\text { Mengorganisasikan } \\
\text { bahan pembelajaran }\end{array}$ & 3 & 3 & 1 & 3 & 1 & 2.20 & 55.00 \\
\hline 3 & $\begin{array}{l}\text { Menentukan strategi } \\
\text { mengajar }\end{array}$ & 4 & 4 & 4 & 4 & 4 & 4.00 & 100.00 \\
\hline 4 & Menentukan langkah- & 4 & 3 & 4 & 4 & 3 & 3.60 & 90.00 \\
\hline
\end{tabular}


Ability : Journal of Education and Social Analysis

Volume 2, Issue 3, Juli 2021

Page : 70-82

\begin{tabular}{|c|l|c|c|c|c|c|c|c|}
\hline & langkah mengajar & & & & & & & \\
\hline 5 & $\begin{array}{l}\text { Menentukan alokasi } \\
\text { waktu }\end{array}$ & 2 & 3 & 1 & 3 & 4 & 2.60 & 65.00 \\
\hline 6 & $\begin{array}{l}\text { Menentukan sumber, } \\
\text { media, dan alat }\end{array}$ & 4 & 2 & 4 & 2 & 2 & 2.80 & 70.00 \\
\hline 7 & $\begin{array}{l}\text { Menentukan bentuk, } \\
\text { prosedur, dan alat } \\
\text { penilaian }\end{array}$ & 3 & 3 & 3 & 3 & 3 & 3.00 & 75.00 \\
\hline Skor maksimal ideal (28) & 23 & 21 & 20 & 22 & 20 & 21 & 75.71 \\
\hline$\%$ & 82.14 & 75.00 & 71.43 & 78.57 & 71.43 & & \\
\hline
\end{tabular}

Rata-rata skor tertinggi yang diperoleh guru adalah $82,14 \%$ dan terendah 71,43\%. Dari data tersebut juga diketahui bahwa terdapat aspek yang masih rendah dalam penyusunan RPP yaitu pada aspek pengorganisasian bahan pembelajaran (55\%) dan menentukan alokasi waktu (65\%). Hasil observasi pelaksanaan pembelajaran guru pada siklus 1 diperoleh data sebagai berikut:

Tabel 2. Rekapitulasi kemampuan guru melaksanakan pembelajaran Siklus 1

\begin{tabular}{|c|c|c|c|c|c|c|c|c|}
\hline \multirow{2}{*}{ NO } & \multirow{2}{*}{ Tahapan yang dinilai } & \multicolumn{5}{|c|}{ GURU } & \multicolumn{2}{|c|}{ Rata-Rata } \\
\hline & & G1 & G2 & G3 & G4 & G5 & Skor & $\%$ \\
\hline 1 & Orientasi & 4.00 & 3.00 & 3.33 & 3.00 & 2.00 & 3.07 & 76.65 \\
\hline 2 & Merumuskan masalah & 3.33 & 3.67 & 2.67 & 2.33 & 3.33 & 3.07 & 76.65 \\
\hline 3 & Merumuskan hipotesa & 1.67 & 0.33 & 1.33 & 1.33 & 0.67 & 1.07 & 26.65 \\
\hline 4 & $\begin{array}{l}\text { Melakukan penyelidikan/ } \\
\text { mengumpulkan data }\end{array}$ & 3.00 & 3.67 & 4.00 & 3.00 & 2.67 & 3.27 & 81.70 \\
\hline 5 & $\begin{array}{l}\text { Menganalisis data/ } \\
\text { menguji hipotesis }\end{array}$ & 2.67 & 3.00 & 3.00 & 3.00 & 2.67 & 2.87 & 71.70 \\
\hline 6 & Merumuskan kesimpulan & 3.00 & 3.00 & 2.33 & 2.67 & 3.33 & 2.87 & 71.65 \\
\hline & JUMLAH SKOR & 17.67 & 16.67 & 16.67 & 15.33 & 14.67 & 16.20 & \\
\hline & \% PENCAPAIAN & 73.61 & 69.44 & 69.44 & 63.89 & 61.11 & 67.50 & \\
\hline
\end{tabular}

Hasil observasi kemampuan mengajar guru dalam menerapkan strategi pembelajaran inkuiri hanya mencapai $73,61 \%$ dengan skor terendah $61,11 \%$. Berdasarkan data tersebut diketahui bahwa aspek tahapan yang paling rendah adalah merumuskan hipotesa $(26,65 \%)$ sedangkan aspek lainnya telah mencapai di atas 70\%. Rekapitulasi nilai hasil belajar siswa pada masingmasing kelas guru subjek diperoleh data sebagai berikut; 
Ability : Journal of Education and Social Analysis

Volume 2, Issue 3, Juli 2021

Page : 70-82

Tabel 3. Persentase ketuntasan klasikal hasil belajar siswa dengan menggunakan strategi pembelajaran inkuiri siklus 1

\begin{tabular}{|c|c|c|c|c|c|c|c|c|}
\hline No & $\begin{array}{c}\text { Kode } \\
\text { Guru }\end{array}$ & $\begin{array}{c}\text { Mata } \\
\text { Pelajaran }\end{array}$ & Kelas & KKM & $\begin{array}{c}\text { Nilai } \\
\text { Rata- } \\
\text { Rata }\end{array}$ & $\begin{array}{c}\text { Jumlah } \\
\text { Siswa }\end{array}$ & $\begin{array}{c}\text { Jumlah } \\
\text { Siswa } \\
\text { Tuntas }\end{array}$ & $\begin{array}{c}\% \\
\text { Klasikal }\end{array}$ \\
\hline 1 & G1 & Biologi & X MIPA & 76 & 90.71 & 21 & 21 & 100.00 \\
\hline 2 & G2 & Ekonomi & X IPS & 70 & 71.62 & 21 & 17 & 80.95 \\
\hline 3 & G3 & Fisika & X MIPA & 75 & 90.48 & 21 & 21 & 100.00 \\
\hline 4 & G4 & Geografi & X IPS & 80 & 85.95 & 21 & 18 & 85.71 \\
\hline 5 & G5 & Kimia & \multicolumn{7}{|c|}{ X MIPA } & 76 & 79.57 & 21 & 17 & 80.95 \\
\hline \multicolumn{7}{|c|}{ Rata-Rata } \\
\hline
\end{tabular}

Persentase ketuntasan belajar siswa pada masing-masing kelas guru subjek diketahui bahwa terdapat 2 kelas yang memiliki ketuntasan klasikal di bawah $85 \%$, yakni berada pada ketuntasan $80,95 \%$. Rekapitulasi rata-rata kemampuan guru dalam menerapkan strategi pembelajaran inkuiri siklus 1 dirangkum pada tabel berikut:

Tabel 4. Rekapitulasi rata-rata kemampuan guru menerapkan SPI siklus 1

\begin{tabular}{|c|c|c|c|c|}
\hline \multirow[b]{2}{*}{ No } & \multirow[b]{2}{*}{$\begin{array}{l}\text { Kode } \\
\text { Guru }\end{array}$} & \multicolumn{3}{|c|}{ Aspek Kemampuan dan Hasil Belajar Siswa } \\
\hline & & $\begin{array}{c}\text { Penyusunan } \\
\text { RPP }\end{array}$ & $\begin{array}{c}\text { Pelaksanaan } \\
\text { SPI }\end{array}$ & $\begin{array}{c}\% \\
\text { Klasikal }\end{array}$ \\
\hline 1 & G1 & 82.14 & 73.61 & 100.00 \\
\hline 2 & G2 & 75.00 & 69.44 & 80.95 \\
\hline 3 & G3 & 71.43 & 69.44 & 100.00 \\
\hline 4 & G4 & 78.57 & 63.89 & 85.71 \\
\hline 5 & G5 & 71.43 & 61.11 & 80.95 \\
\hline \multicolumn{2}{|c|}{ Rata-Rata } & 75.71 & 67.50 & 89.52 \\
\hline
\end{tabular}

Sesuai dengan tabel tersebut diketahui bahwa rata-rata kemampuan guru dalam menyusun RPP adalah 75,71\% dimana skor tertinggi hanya mencapai $82,14 \%$. Rata-rata skor kemampuan guru melaksanakan SPI adalah 67,50\% dengan skor tertinggi hanya mencapai 73, 61\% dengan rata-rata. Namun persentase klasikal ketuntasan belajar siswa, terdapat 2 kelas yang hanya ketuntasan klasikal 80,95\%. 
Ability : Journal of Education and Social Analysis

Volume 2, Issue 3, Juli 2021

Page : $70-82$

Selanjutnya data tersebut digambarkan pada diagram berikut:

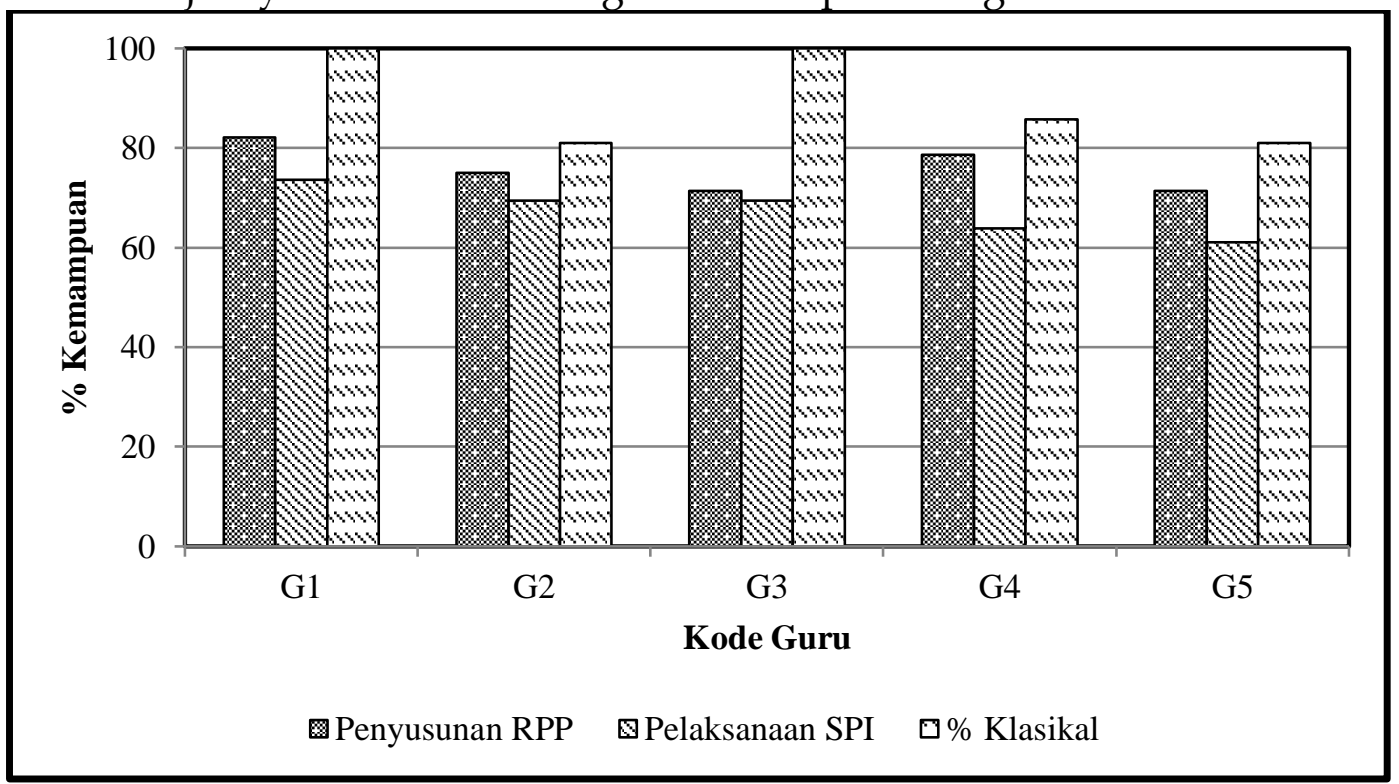

Gambar 1. Diagram kemampuan guru menerapkan SPI siklus 1

a. Pelaksanaan program coaching telah dilakukan sesuai dengan 6 tahapan yang ada sesuai dengan pengamatan observer, kemudian peneliti menerima masukan dari kepala sekolah/ wakil kurikulum yang bertindak sebagai observer kegiatan, yaitu sebaiknya intensitas pertemuan individual ditambahkan lagi, kemudian pada saat melaksanakan refleksi/ umpan balik dengan guru sebaiknya melibatkan pihak ketiga (observer lainnya).

b. Pada saat melaksanakan diskusi coaching secara perorangan diketahui bahwa terdapat guru yang masih belum terbiasa dengan program coaching, hal ini tampak ketika guru mengakui belum membaca literasi tentang konsep strategi pembelajaran inkuiri yang telah diberikan sebelumnya untuk dibahas pada pertemuan coaching di hari itu. Kemudian, terjadi pengunduran waktu pelaksanan coaching individu.

c. Guru merasa senang dengan adanya pendampingan yang rutin sampai ke kelas dari pihak yang lebih menguasai keahlian tertentu seperti coaching, namun karena guru belum terbiasa dengan program tersebut, sehingga guru masih merasa terburu-buru untuk mempersiapkankan segala bahanbahan perencanaan pembelajaran.

d. Berdasarkan data dan diagram di atas, diketahui bahwa kemampuan guru dalam menerapkan strategi pembelajaran inkuiri belum mencapai indikator keberhasilan yaitu $85 \%$, rata-rata kemampuan guru merencanakan pembelajaran baru mencapai $71,43 \%$ dengan indikator terendah adalah mengorganisasikan bahan ajar dan mengalokasikan waktu kemudian ratarata kemampuan guru melaksanakan pembelajaran inkuiri baru mencapai $67,50 \%$, dengan indikator terendah adalah merumuskan hipotesa. Ketuntasan klasikal siswa di setiap kelasnya belum seluruhnya mencapai $85 \%$ terdapat 2 kelas dengan ketuntasan klasikal 80,95\%. Sehingga 
Ability : Journal of Education and Social Analysis

Volume 2, Issue 3, Juli 2021

Page : 70-82

penelitian dilanjutkan pada siklus kedua dengan mempertimbangkan kelemahan-kelemahan pada siklus pertama.

Refleksi siklus kedua dilakukan dengan melihat catatan pengamatan dan wawancara selama kegiatan berlangsung. Hasil telaah kemampuan guru menyusun RPP dipaparkan dalam tabel berikut:

Tabel 5. Rekapitulasi kemampuan guru menyusun RPP Siklus 2

\begin{tabular}{|c|c|c|c|c|c|c|c|c|}
\hline \multirow{2}{*}{ NO } & \multirow{2}{*}{ Aspek Yang Dinilai } & \multicolumn{5}{|c|}{ Guru } & \multicolumn{2}{|c|}{ Rata-Rata } \\
\hline & & G1 & G2 & G3 & G4 & G5 & Skor & $\%$ \\
\hline 1 & $\begin{array}{l}\text { Kemampuan } \\
\text { merumuskan tujuan } \\
\text { pembelajaran }\end{array}$ & 4 & 4 & 4 & 4 & 4 & 4.00 & 100.00 \\
\hline 2 & $\begin{array}{l}\text { Kemampuan } \\
\text { mengorganisasikan } \\
\text { bahan pembelajaran }\end{array}$ & 4 & 4 & 3 & 3 & 3 & 3.40 & 85.00 \\
\hline 3 & $\begin{array}{l}\text { Kemampuan } \\
\text { menentukan strategi } \\
\text { mengajar }\end{array}$ & 4 & 4 & 4 & 4 & 4 & 4.00 & 100.00 \\
\hline 4 & $\begin{array}{l}\text { Kemampuan } \\
\text { menentukan langkah- } \\
\text { langkah mengajar }\end{array}$ & 4 & 4 & 4 & 4 & 4 & 4.00 & 100.00 \\
\hline 5 & $\begin{array}{l}\text { Kemampuan } \\
\text { menentukan alokasi } \\
\text { waktu }\end{array}$ & 4 & 4 & 4 & 4 & 3 & 3.80 & 95.00 \\
\hline 6 & $\begin{array}{l}\text { Kemampuan } \\
\text { menentukan sumber, } \\
\text { media, dan alat }\end{array}$ & 4 & 4 & 4 & 4 & 4 & 4.00 & 100.00 \\
\hline 7 & $\begin{array}{l}\text { Kemampuan } \\
\text { menentukan bentuk, } \\
\text { prosedur, dan alat } \\
\text { penilaian }\end{array}$ & 4 & 4 & 4 & 4 & 4 & 4.00 & 100.00 \\
\hline & kor maksimal ideal $=28$ & 28 & 28 & 27 & 27 & 26 & 27.2 & 97.14 \\
\hline & $\%$ & 100.00 & 100.00 & 96.43 & 96.43 & 92.86 & & \\
\hline
\end{tabular}

Berdasarkan data tersebut diketahui bahwa rata-rata kemampuan guru menyusun RPP adalah 97,14\% dengan skor terendah adalah 92,86\%. Kemudian aspek yang terendah adalah pengorganisasian bahan pembelajaran dan menentukan alokasi, namun telah mencapai minimal 95\%. Hasil observasi kemampuan mengajar guru dalam menerapkan strategi pembelajaran inkuiri pada siklus 2 disajikan pada tabel di bawah ini: 
Ability : Journal of Education and Social Analysis

Volume 2, Issue 3, Juli 2021

Page : 70-82

Tabel 5. Rekapitulasi kemampuan guru melaksanakan pembelajaran Siklus 2

\begin{tabular}{|c|c|c|c|c|c|c|c|c|}
\hline \multirow{2}{*}{ No } & \multirow{2}{*}{ Tahapan yang dinilai } & \multicolumn{5}{|c|}{ Guru } & \multicolumn{2}{|c|}{ Rata-Rata } \\
\hline & & G1 & G2 & G3 & G4 & G5 & Skor & $\%$ \\
\hline 1 & Orientasi & 4.00 & 4.00 & 2.67 & 4.00 & 4.00 & 3.73 & 93.35 \\
\hline 2 & Merumuskan masalah & 4.00 & 4.00 & 4.00 & 3.33 & 4.00 & 3.87 & 96.65 \\
\hline 3 & Merumuskan hipotesa & 2.67 & 3.67 & 4.00 & 2.67 & 2.00 & 3.00 & 75.05 \\
\hline 4 & $\begin{array}{l}\text { Melakukan penyelidikan/ } \\
\text { mengumpulkan data }\end{array}$ & 3.67 & 3.67 & 3.67 & 3.67 & 4.00 & 3.74 & 93.40 \\
\hline 5 & $\begin{array}{l}\text { Menganalisis data/ menguji } \\
\text { hipotesis }\end{array}$ & 4.00 & 2.33 & 3.67 & 3.67 & 4.00 & 3.53 & 88.35 \\
\hline 6 & Merumuskan kesimpulan & 3.00 & 3.00 & 3.00 & 3.33 & 2.67 & 3.00 & 75.00 \\
\hline & Jumlah skor & 21.34 & 21.00 & 21.00 & 20.67 & 20.67 & 20.94 & \\
\hline & $\%$ Pencapaian & 88.89 & 87.50 & 87.50 & 86.11 & 86.11 & 87.22 & \\
\hline
\end{tabular}

Dari tabel tersebut diketahui bahwa, rata-rata skor kemampuan guru melaksanakan SPI telah mencapai 87,22\% dengan skor terendah 85,70\%. Dilihat dari tahapan SPI yang dinilai rata-rata skor terendah adalah $75 \%$ yakni pada tahapan merumuskan hipotesa dan merumuskan kesimpulan. Persentase ketuntasan belajar siswa pada masing-masing kelas guru subjek telah mencapai ketuntasan klasikal terendah 85,71\% dengan rata-rata \% klasikal 95,24\% yang dipaparkan pada tabel di bawah ini:

Tabel 6. Persentase ketuntasan klasikal siswa dengan menerapkan strategi pembelajaran inkuiri siklus 2

\begin{tabular}{|c|c|c|c|c|c|c|c|r|}
\hline $\begin{array}{c}\mathbf{N} \\
\mathbf{0}\end{array}$ & $\begin{array}{c}\text { Kod } \\
\mathbf{e} \\
\text { Gur } \\
\mathbf{u}\end{array}$ & $\begin{array}{c}\text { Mata } \\
\text { Pelajaran }\end{array}$ & Kelas & $\begin{array}{c}\text { KK } \\
\mathbf{M}\end{array}$ & $\begin{array}{c}\text { Nilai } \\
\text { Rata } \\
- \\
\text { Rata }\end{array}$ & $\begin{array}{c}\text { Jumla } \\
\mathbf{h} \\
\text { Siswa }\end{array}$ & $\begin{array}{c}\text { Jumla } \\
\mathbf{h} \\
\text { Siswa } \\
\text { Tuntas }\end{array}$ & $\begin{array}{c}\% \\
\text { Klasikal }\end{array}$ \\
\hline 1 & G1 & Biologi & X MIPA & 78 & 90.90 & 21 & 21 & 100.00 \\
\hline 2 & G2 & Ekonomi & X IPS & 73 & 76.67 & 21 & 19 & 90.48 \\
\hline 3 & G3 & Fisika & X MIPA & 73 & 95.24 & 21 & 21 & 100.00 \\
\hline 4 & G4 & Geografi & X IPS & 75 & 94.33 & 21 & 21 & 100.00 \\
\hline 5 & G5 & Kimia & X MIPA & 77 & 81.19 & 21 & 18 & 85.71 \\
\hline \multicolumn{7}{|c|}{ Rata-rata } \\
\hline
\end{tabular}

Rekapitulasi rata-rata kemampuan guru dalam menerapkan strategi pembelajaran inkuiri siklus 2 dirangkum pada tabel berikut:

Tabel 7. Rekapitulasi rata-rata kemampuan guru menerapkan SPI siklus 2

\begin{tabular}{|c|c|c|c|c|}
\hline \multirow{2}{*}{ No } & \multirow{2}{*}{$\begin{array}{c}\text { Kode } \\
\text { Guru }\end{array}$} & \multicolumn{3}{|c|}{ Aspek Kemampuan dan Hasil Belajar } \\
\cline { 3 - 5 } & & $\begin{array}{c}\text { Penyusunan } \\
\text { RPP }\end{array}$ & $\begin{array}{c}\text { Pelaksanaan } \\
\text { SPI }\end{array}$ & $\begin{array}{c}\text { \% } \\
\text { Klasikal }\end{array}$ \\
\hline 1 & G1 & 100.00 & 88.89 & 100.00 \\
\hline 2 & G2 & 100.00 & 87.50 & 90.48 \\
\hline 3 & G3 & 96.43 & 87.50 & 100.00 \\
\hline
\end{tabular}


Ability : Journal of Education and Social Analysis

Volume 2, Issue 3, Juli 2021

Page : 70-82

\begin{tabular}{|c|c|c|c|c|}
4 & G4 & 96.43 & 86.11 & 100.00 \\
\hline 5 & G5 & 92.86 & 86.11 & 85.71 \\
\hline \multicolumn{2}{|c|}{ Rata-rata } & 97.14 & 87.22 & 95.24 \\
\hline
\end{tabular}

Berdasarkan data di atas, maka diketahui bahwa persentase skor rata-rata kemampuan guru menyusun RPP adalah 97,14\% dengan skor terendah 85,71\%. Kemudian kemampuan guru melaksanakan SPI mencapai rata-rata 87,22\% dengan skor terendah $87,50 \%$ dan persentase klasikal ketuntasan belajar siswa mencapai rata-rata 95,24\% dengan ketuntasan klasikal terendah 85,71\%. Data tersebut selanjutnya digambarkan pada diagram berikut ini:

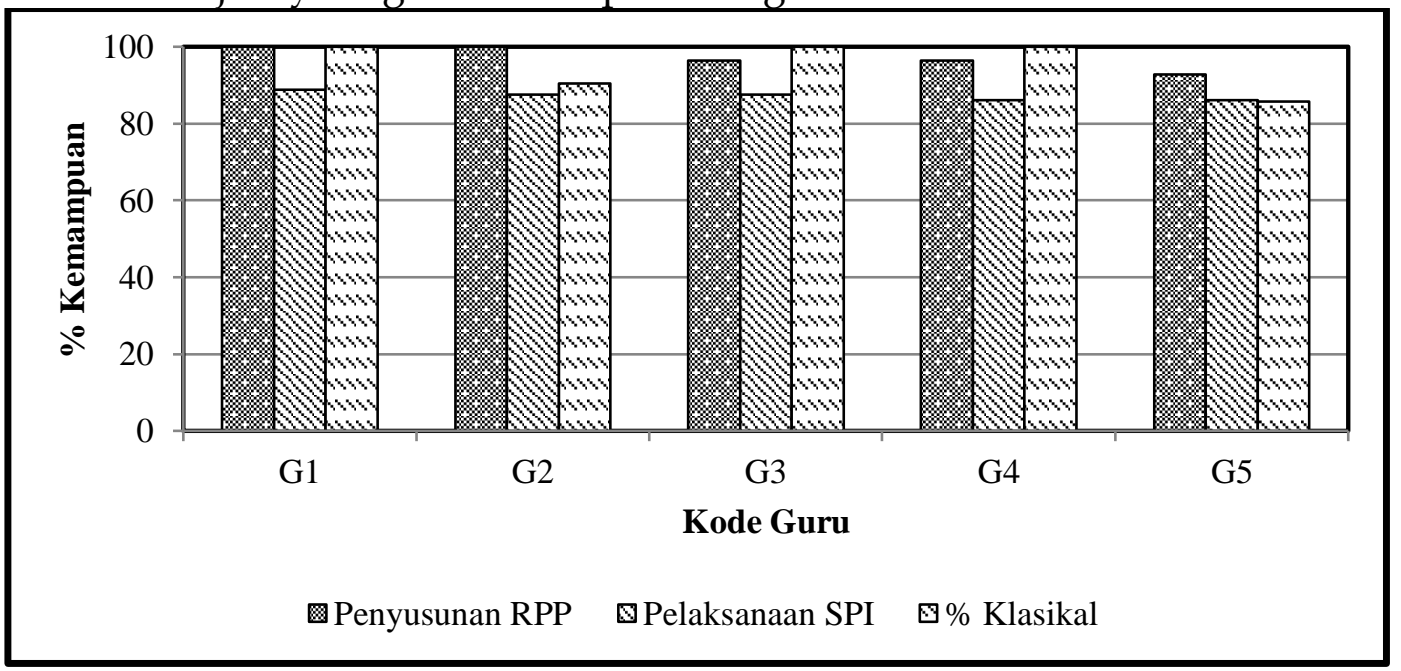

Gambar 2. Diagram kemampuan guru menerapkan pembelajaran SPI siklus 2

a. Pelaksanaan tahapan progam coaching terlaksana seluruhnya, namun begitu observer menyarankan untuk lebih menyinggung pada aspek emosional guru seperti motivasi dan komitmen.

b. Pada umumnya guru merasa puas dengan pelaksanaan coaching siklus kedua, karena telah terbiasa didampingi dalam kegiatan perencanaan maupun pelaksanaan pembelajaran di kelas.

c. Berdasarkan data pada tabel dan diagram di atas, maka diketahui bahwa kemampuan guru dalam menyusun RPP dan melaksanakan SPI pada siklus 2 telah mencapai indikator keberhasilan (85\%), ketuntasan klasikal siswa telah berada di atas $85 \%$ di setiap kelasnya yakni ketuntasan klasikal terendah $85,71 \%$, serta $100 \%$ guru telah dapat menerapkan SPI. Sehingga penelitian tidak perlu dilanjutkan pada siklus berikutnya.

\section{Pembahasan}

Pada siklus pertama diketahui bahwa rata-rata kemampuan guru dalam menyusun RPP adalah $75,71 \%$ dimana masih terdapat skor rendah pada aspek mengorganisasikan bahan ajar, menentukan alokasi waktu, dan menentukan sumber/ media ajar. Hal ini disebabkan ada guru yang tidak menjabarkan bahan ajar secara sistematis dan sesuai kaedah ilmiah, membagi waktu dalam setiap langkah secara proporsional, dan juga tidak mengembangkan penilaian sesuai dengan tujuan pembelajaran. Sementara rata-rata kemampuan guru 
Page : 70-82

melaksanakan SPI di kelas adalah 71,65\% dengan skor terendah adalah pada perumusan hipotesa. Hal ini terjadi karena dalam merumuskan hipotesa, guru tidak menfokuskan satu dari beberapa masalah yang dipaparkan sehingga siswa kurang memahami arah pembicaraan guru dan ada guru yang langsung merumuskan masalah tersebut bukan mengarahkannya kepada siswa melalui pertanyaan-pertanyaan. Aspek yang juga rendah adalah pada analisa data dimana ada guru yang tidak memberikan form khusus untuk mengarahkan siswa menyimpulkan data penyelidikan, juga perumusan kesimpulan, dimana guru tidak memberikan data yang relevan untuk penguatan siswa dan pemberian pujian terhadap siswa yang telah bersedia memberikan kesimpulannya.

Dilihat dari ketuntasan hasil belajar klasikal siswa pada siklus 1 diperoleh rata-rata ketuntasan klasikal 89,52\%. Jika dibandingkan dengan kondisi awal maka terjadi peningkatan yang semula hanya mencapai rata-rata 70\% disetiap akhir pembelajaran. Dapat dikatakan bahwa penerapan SPI memberikan pengaruh pada ketuntasan hasil belajar klasikal siswa.

Pada siklus kedua terjadi peningkatan rata-rata kemampuan guru menyusun RPP yakni menjadi 97,14\% dimana skor terendah ada pada aspek mengorganisasikan bahan pelajaran (85\%). Hal ini dikarenakan terdapat guru yang mencantumkan bahan ajar yang tidak sesuai dengan kaedah ilmiah yakni tidak dijabarkan dari yang umum ke yang khusus beserta contoh yang relevan. Namun, secara keseluruhan kemampuan guru menyusun RPP telah mencapai indikator keberhasilan tindakan yakni di atas $85 \%$. Kemudian, rata-rata kemampuan guru melaksanakan SPI telah mencapai 87,22\%, meskipun terdapat guru yang masih lemah dalam merumuskan hipotesa dan merumuskan kesimpulan yang disebabkan guru tidak mengarahkan siswa untuk merumuskan hipotesanya sebelum penyelidikan dan guru lupa memberikan data yang relevan dalam penguatan yang disampaikan di akhir pembelajaran. Secara keseluruhan rata-rata kemampuan guru melaksanakan SPI pada siklus 2 telah mencapai indikator keberhasilan. Ditinjau dari persentase ketuntasan klasikal siswa pada siklus 2 telah mencapai 95,24\%. Sehingga terjadi peningkatan pada hasil belajar siswa dengan menerapkan SPI dengan tingkat rata-rata KKM antara $73-78$.

Selanjutnya data peningkatan rata-rata kemampuan guru dalam menerapkan strategi pembelajaran inkuiri disajikan dalam tabel berikut:

Tabel 8. Rekapitulasi rata-rata kemampuan guru menerapkan SPI

\begin{tabular}{|c|c|c|c|c|l|}
\hline \multirow{2}{*}{ No } & \multirow{2}{*}{$\begin{array}{c}\text { Aspek } \\
\text { Penilaian }\end{array}$} & \multicolumn{3}{|c|}{ Rata-rata \% kemampuan } & \multirow{2}{*}{ Keterangan } \\
\cline { 3 - 5 } & Prasiklus & Siklus 1 & Siklus 2 & \\
\hline 1 & $\begin{array}{c}\text { Penyusunan } \\
\text { RPP }\end{array}$ & 60.71 & 75.71 & 97.14 & Meningkat \\
\hline 2 & $\begin{array}{c}\text { Pelaksanaan } \\
\text { SPI }\end{array}$ & 34.17 & 67.50 & 87.22 & Meningkat \\
\hline
\end{tabular}


Page : $70-82$

\begin{tabular}{|c|c|c|c|c|}
\hline Rata-Rata & 47.44 & 71.61 & 92.18 & Meningkat \\
\hline
\end{tabular}

Dari tabel tersebut diketahui bahwa terjadi peningkatan kemampuan guru dalam menerapkan strategi pembelajaran inkuiri sebesar $24,17 \%$ yaitu dari $47,44 \%$ pada kondisi awal menjadi $71,61 \%$ pada siklus 1 dan meningkat menjadi $92,18 \%$ pada siklus 2 dengan peningkatan sebesar $20,57 \%$. berikut:

Selanjutnya data tersebut dapat digambarkan dalam diagram sebagai

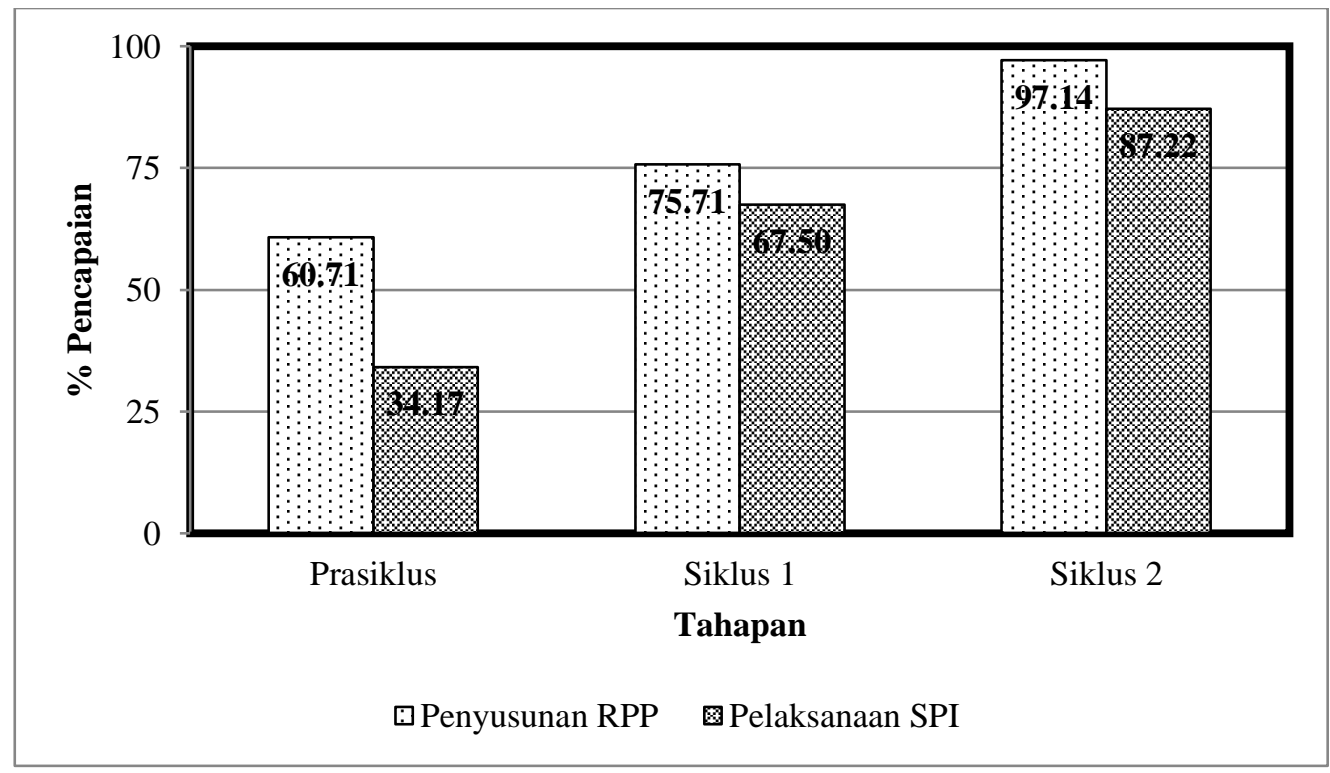

Gambar 3. Diagram rata-rata kemampuan guru menerapkan SPI

Pada penelitian ini ditemukan bahwa perbedaan kemampuan mengajar guru dalam merencanakan dan melaksanakan SPI juga dipengaruhi oleh tingkat pengalaman guru baik dari masa kerja maupun pelatihan yang pernah diikuti. Selain itu ditemukan juga kondisi emosional dan sosial guru juga turut mempengaruhi baik buruknya kinerja guru, hal ini tampak pada kondisi emosional guru pada pertemuan informal pada saat coaching individual, yang tampak pada konsisten tidaknya guru mengikuti jadwal coaching yang telah disepakati dan juga penyerahan salinan RPP/ bahan ajar. Sehingga coach ataupun pelaksana supervisi akademik sebaiknya lebih mentolerir tingkat abstraksi maupun emosi guru pada saat program coaching berlangsung.

\section{KESIMPULAN}

Dari hasil penelitian dan pembahasan penelitian maka dapat ditarik simpulan bahwa ;

1. Penerapan supervisi akademik berbasis coaching dapat meningkatkan kemampuan Guru dalam menerapkan strategi pembelajaran inkuiri di MAN 2 Ketapang.

2. Peningkatan kemampuan guru terbaca dari peningkatan persentase skor siklus 1 dan siklus 2 dalam hal: 
Page : $70-82$

a. Menyusun RPP dari skor rata-rata $75,71 \%$ meningkat menjadi $97,14 \%$

b. Melaksanakan strategi pembelajaran inkuiri dari skor rata-rata $67,50 \%$ meningkat menjadi $87,22 \%$

3. Penerapan strategi pembelajaran inkuiri memiliki pengaruh terhadap pencapaian hasil belajar siswa. Hal ini terbaca dari peningkatan rata-rata persentase ketuntasan klasikal siswa dari $89,52 \%$ pada siklus 1 meningkat menjadi 95,24\% pada siklus 2 .

\section{DAFTAR PUSTAKA}

Ali, M. 2006. Pengembangan Kurikulum di Sekolah. Sinar Baru. Bandung.

Arninditha, N. 2012. Pemberian Coaching Dan Konseling Untuk Meningkatkan Perilaku Proaktif Dan Menurunkan Intensi Untuk Keluar Pada Excecutive Trainee Batch 4 Di PT.XYZ. Tesis. Universitas Indonesia. Jakarta.

Aqib, Z \& Rohmanto, E.2007. Membangun Profesionalisme Guru dan Pengawas Sekolah. Yrama widya. Bandung.

Arifin, M dkk. 2000. Strategi Belajar Mengajar Kimia. Jurusan Pendidikan Kimia Universitas Pendidikan Indonesia. Bandung.

Colburn, A. 2000. An Inquiry Primer. Science Scope Journal. Tersedia : http://www.nsta.org/main/news/pdf. Diakses tanggal 17 Oktober 2013.

Depdiknas. 2008. Strategi Pembelajaran dan Pemilihannya. Ditjen PMPTK Depdiknas. Jakarta

Glickman, C. 2002. Leadership For Learning : How To Help Teachers Succeed. Association for Supervision and Curriculum Development. Alexandria, Virginia USA.

Harahap, B. 1983. Supervisi Pendidikan yang Dilaksanakan oleh Guru, Kepala Sekolah, Penilik dan Pengawas Sekolah. Damai Jaya. Jakarta.

Holliday, M. 2001. Coaching, Mentoring E Managing. Career Press Inc. Franklin Lakes New Jersey.

Joyce, dkk. 2011. Models Of Teaching. Edisi Kedelapan. Penerjemah : Achmad Fawaid. Pustaka Pelajar. Yogyakarta.

Juli, M. 2013. 50 Persen Guru di Aceh Tidak Layak Mengajar. Tersedia: http://theglobejournal.com/pendidikan/50-persen-guru-di-aceh-tidak layak-mengajar/index.php.

Kemdikbud. 2013. Bahan Pelatihan Implementasi Kurikulum 2013: Supervisi Pembelajaran Pada Kurikulum 2013 Terhadap Guru dan Kepala Sekolah. Badan Pengembangan Sumber Daya Manusia Pendidikan dan Kebudayaan dan Penjaminan Mutu Pendidikan Kementerian Pendidikan dan Kebudayaan. Jakarta.

Koes, S. 2003. Strategi Pembelajaran Fisika. Universitas Negeri Malang. Malang.

Lovel, J dan Wiles, K. 1983. Supervision For Better School. Fifth Edition. PrenticeHall Inc. New Jersey

Mulyasa, E. 2005. Menjadi Guru Profesional. Remaja Rosdakarya. Bandung. 
2013. Pengembangan dan Implementasi Kurikulum 2013. Remaja Rosdakarya. Bandung.

Muslim, SB. 2010. Supervisi Pendidikan Meningkatkan Kualitas Profesionalisme Guru. Alfabeta. Bandung.

Nugroho, dkk. 2011. Pengaruh Coaching Terhadap Motivasi Kerja dan Kinerja Individual (Studi Kasus pada Karyawan Bagian Support Services Departemen Production Services PT. International Nikel Indonesia, Tbk). Jurnal. Tersedia : http:/ / pasca.unhas.ac.id/jurnal/ diakses tanggal 1 September 2013.

Paulus, M. 2013. Peningkatan Kemampuan Guru Dalam Mengelola Pembelajaran Perbaikan (Remedial Teaching) Mata Pelajaran Bahasa Indonesia Melalui Peer Coaching. Laporan Penelitian. Tersedia : http://lpmp.wordpress.com diakses tanggal 19 September 2013. LPMP Jawa Tengah.

Prasojo, L D \& Sudiyono. 2011. Supervisi Pendidikan. Gava Media. Yogyakarta.

Puskur Balitbang Depdiknas. 2007. Kajian Kebijakan Mata Pelajaran IPA. Depdiknas. Jakarta

Rae, L. 2005. The Art Of Training and Development : Effective Planning. Alih bahasa : Osman Fiyanti. Bhuana Ilmu Populer. Jakarta. . 2005. The Art Of Training and Development : Using People Skills in Training and Development. Alih bahasa : Osman Fiyanti. Bhuana Ilmu Populer. Jakarta.

Riandi, dkk. 2008. Developing Of Video-Based Coaching Package: Results Of The Second Year Research Project. Paper to be presented at "The 2nd International Seminar on Science Education". Bandung 18 October 2008. Department of Biology Education FPMIPA UPI. Bandung.

Sagala, S. 2010. Supervisi Pembelajaran dalam Profesi Pendidikan. Alfabeta. Bandung. 